\title{
Evaluation and Social Internship Program of IAIN Sultan Thaha Saifuddin Jambi Students: Using Context, Input, Process and Product Model (CIPP Model)
}

\author{
M. Hurmaini \\ Department of Islamic Studies, Faculty of Education and Teacher Training, \\ IAIN Sulthan Thaha Saifuddin Jambi, Indonesia \\ E-mail : m.hurmaini@yahoo.co.id \\ DOI: http://dx.doi.org/10.15548/jt.v22i1.114
}

\begin{abstract}
The purpose of the research is to know the context, input, process and product evaluation on the Social Internship Program (Kukerta) of IAIN Sulthan Thaha Saifuddin Jambi Students by using Participatory Action Research (PAR) system. The research is conducted in four locations of IAIN Sultan Thaha Saifuddin Jambi students' Kukerta in first period of 2013; Lubuk Terap, Sengeti Kecamatan Sekernan, unas, and Simpang Tiga Sipin by using questionnaire. All students of Kukerta in these 4 locations, consists of 51 people become the sample of this study. The finding of the study showed that first, context evaluation of PAR system Kukerta programs is actually having many deficiencies and weakness in both determining the needs as well as the purpose of Kukerta program. Therefore, it needs some improvements or revision. Second, input evaluation of PAR system Kukerta shows some weakness from the students and the internship supervisors/ advisors. Both students and internship supervisors have to be firstly provided by training on PAR system Kukerta. Third, process evaluation on the program is also lack of the relevant activities towards students' needs and program realization. Fourth, product evaluation reveals that there is no significant result of the program, physically or non-physically. It can be recommended that the program can be continued with some improvements and revision on its implementation.
\end{abstract}

Keywords : CIPP Model, Social Internship Program, PAR System

\section{INTRODUCTION}

Social Internship Program (to be called Kukerta), is one part of vital activities that integrates the three university philosophy; education, research and social work on field/ society. It is a foundation for the students to get some experiences and skills while also provides as the moment of social devotion to take part in developing the rural society.

In fact, Kukerta program that had been implemented by IAIN Sultan Thaha Saifuddin Jambi has not met its objectives yet, as what it is expected. Although the students get an adequate scores, but the implementation of the Kukerta is still facing many problems. Kukerta Program by PAR (Participatory Action Research) System was implemented for 4 periods, with no evaluation on the program itself.
PAR System Kukerta is different with the former system. Kukerta by using this system focuses on the comprehensive involvement of the society as the sources and centre of students learning. The needs of society/ inhabitants have to be firstly known before arranging the programs. The social reflective-program implementation is done by the students along with the society.

This implementation, however, needs an evaluation process. Evaluation is an important step to do, since it is hardly supportive to make a successful program. Moreover it can make Kukerta to be more meaningful for both students and the society. Evaluation also helps us to know the barriers while the program is conducting. Thus, it will lead to such solution and improvement. 
A program without evaluation is an incompetent thing since the effect would not be able to be measured. When this happens, the academic policy will be difficult to take. Therefore, the researcher thinks that it is important to conduct a research on Social Internship Program of IAIN Sulthan Thaha Saifuddin Jambi.

Based on the evaluation, the strength and the weakness of Kukerta Program can be described. This also can be seen as a basic of ruling such a feedback to improve or revise the forthcoming program.

The problem that will be answered through the study is: How is the context, input, process and result evaluation on PAR system Kukerta program of IAIN Sultan Thaha Saifudin Jambi students ? The purpose of the research is to describe the context, input, process and product evaluation on the Social Internship Program (Kukerta) of IAIN Sulthan Thaha Saifuddin Jambi Students by using Participatory Action Research (PAR) system.

\section{METHOD}

The population of the research is all students of Extension Class of IAIN Sultan Thaha Saifudin Jambi who conducted the social internship relationship by using PAR system. They are from $38^{\text {th }}$ genereation, phase I (March - June 2013 ), consists of 145 students. Sample is taken by random sampling. It is based on locations of Kukerta, which are; Desa Lubuk Terap Kecamatan Merlung Kabupaten Tanjungjabung Barat (8 students), Desa Tunas Baru Kecamatan Sekernan (11 students), Desa Sengerti Kecamatan Sekernan Muara Jambi (17 students) and Kelurahan Simpang III Sipin Kecamatan Kotabaru Jambi (15 students). The total is 51 students.

Data collection is done by observation, interview and questionnaires. Questionnaires are used to get data about the relevancy between Kukerta program using PAR system towards students needs and implementation in accordance with the purpose expected. Interview is done to gain more accurate data. It is addressed to Kukerta Executing Board and society on field. Observation is aimed to see the product made by students in implementing the program.

Data analysis is conducted by qualitative descriptive analysis. The data were analyzed by formula of $\mathrm{P}=\mathrm{f} / \mathrm{N} \times 100$.

\section{RESEARCH FINDINGS}

Research findings are focused on four parts; context evaluation, input evaluation, process evaluation and product evaluation or in other words called as CIPP model towards Social Internship Program using PAR system in IAIN Sultan Thaha Saifuddin Jambi.

\section{Context Evaluation towards PAR System Kukerta}

Muri (2005) described that context evaluation is more related to information supply in determining the purposes, formulating relevant surroundings and identifying the problems concerned with learning program and education activities. Context evaluation includes the purpose of the program, the needs that will be fulfilled by the program and also the foundation for determining the decision.

Based on the data about program content evaluation collected by questionnaires, it is known that $43,1 \%$ respondents states that program planning is designed by the university. The program tries to improve the social mindset towards outsiders, so the community is able to increase their life. In short, the students are directed by the university / academic plan, but it is adjustable to the field condition.

About 39.2\% respondents said that they follow the design that formerly arranged and implement it as what directed. Program planning of PAR system Kukerta is made daily, weekly or monthly. Some follow their senior. This planning, however, is recommended to be daily, to make sure that everything is in detail and easily monitored.

About $66.7 \%$ of respondents described that implementation of the program is agreed with existing condition on field. Most of the Merlung people are having the high religious understanding, while some are not. There are 
some Kukerta activity that cannot be implemented on field because of the lack of social spiritual concerns (Islam). This forces the students to find another program that are suitable with the existing condition.

Coaching before the implementation of Kukerta was assumed to be unsatisfactory ( shown by $51 \%$ respondents). It is held by the university. The subject given has not fulfilled the students needs. The materials / subjects of such coaching are mapping, transector, venn diagram, purpose analysis, steps on implementation of PAR system Kukerta, method and strategies that can be applied and also about local condition.

About 35.3\% respondents claimed that the Kukerta budgeting is funded by students and supported by university. The ones funded by campus are transportation and accommodation.

Early observation on location is supported by $66.7 \%$ respondents. Observation is seen to be effective in gaining the information about local condition.

Besides, related to the basic knowledge of program, purpose and activities of PAR system Kukerta, $64.7 \%$ respondents said that they just have general understanding. The subject become more clearer after having / getting a coaching given by campus.

Related to location, $68.8 \%$ said that it was far from the local / regency government. It is on Kecamatan Merlung. The location can be accessed by cars. To reach the city, it needs 3 hours by cars / motorcycle. Means and infrastructure to support the implementation of the program are seen to be unsatisfactory by $62.7 \%$ respondents. The transport provided by the campus while the accommodation served by local people.

About 49\% respondents claimed that the location was less conducive. It happened because of the students were not adaptable to the surroundings. The people tended to keep the distance and this made support for the program was less.

In general, context evaluation shows that PAR system Kukerta in IAIN Sultan Thaha
Saifudin Jambi has many weakness and need to be revised or improved especially in determining the purpose and need of the students in executing the program.

\section{Input Evaluation towards PAR system Kukerta Program}

Muri (2005) explained that input evaluation is to establish the way to utilize the input in gaining the purpose. For this reason, it is important to conduct evaluation. Based on the data about input evaluation towards PAR system Kukerta through questionnaire, it is assumed that ; $60.8 \%$ respondents said that the knowledge of PAR system Kukerta is unsatisfactory. It is because of the available or accessible information is decreased. The knowledge of method, strategies, steps on program has just accepted through coaching and on field.

Moreover, concerning with training program of PAR system Kukerta, $51 \%$ respondents stated that they only joined the training held by campus. These data clarifies that the program needs to be revised. From the input, both students and internship supervisors are lack of the practical knowledge that the campus has to provide a more reliable and wellorganized coaching.

\section{Process evaluation towards PAR system Kukerta Program}

Farida (2002) explained that process evaluation could help the implementation of decision, measure the extent of implementation towards the plan and identify the part of program need to be revised.

Based on process evaluation, it is known that $80.4 \%$ respondents assessed that the program designed by campus is relevant with the social condition in which the Kukerta held. $47.1 \%$ respondents stated that the capability of internship supervisors in motivating the students is well recognized. The students really need the guide and support from these lecturers / supervisors. It implies that all supervisors have to be prepared by Diklat PAR system Kukerta, to make sure that their guidance more rewarding and effective. 
The local government supported the Kukerta. They also participated in the program. About 58.5\% respondents described some barriers on field concerned with local custom and tradition.

\section{Product evaluation towards PAR system Kukerta Program}

Farida (2000) also explained that product evaluation is a part of decision making. It guides the steps taken after the program as well as measures the result. This determine the existence of program ; continue, dismiss / stop, revise or developed in other location.

Based on this evaluation, $54.9 \%$ showed that the program provided valuable experience for its students or participants. They were acquainted with social values, the problem of development while identified the solution for its inhabitants.

The physical result is the public restroom, community reading room, the youth organization. There are also other non-physical evidence. The report of Kukerta also attached by mapping, administrative region, field note, venn diagram, ranking matrix and many others.

\section{DISCUSSION}

Based on definition in Oxford Advanced Learner's Dictionary of Current English (1988), evaluation is to find, decide the amount or value. Suharsimi (1988) defines evaluation as a process of collecting data in purpose of establishing the extent, in what extent and how an educational objective has been achieved. If this is not achievable, the reason will be needed to discover and solve. It is stated that evaluation is basically aimed to provide consideration, review or the value based on specific criteria to get a valid and objective evaluation taken from qualitative as well as quantitative information. The instruments must be actual, practical, genuine and well-integrated.

There are many definitions of evaluation, arriving from different books with different experts / writers. Guba and Lincolin ( 1981) stated that evaluation is the process to determine the extent of the purpose has been set up or implemented. Meanwhile, Cronbach and Suppes (1969) said that evaluation is the process of determining the value and effectiveness of an activity to help in making decision. A Joint Committee on Standard for Evaluation (1981) explained evaluation as the process of systematical investigation on the use and benefit of something based on certain standard and criteria. Stufflebeam and Shinkfield (1985) defined it as an activity of comparing between the purpose and the result. The Indonesia Act No.20 ( 2003 ) on National Education System Chapter XVI article 57 states that evaluation is conducted as an effort of controlling the national education quality as a form of academicals accountability to the parties involved.

Ralph and Tyler (1950) explained that evaluation is the process to measure the purpose of education achieved, a way to document the appropriateness between the result of the students and the objective of the program. Moreover, Croncbach (1963), Alkin (1969) and Stufflebeam (1971) approved that evaluation is an activity to collect, to get and to provide information for decision makers. Other opinion, Popham (1969), Provus (1969) and Rivlin (1971) defined that evaluation is the way to comparing data and the real performance based on public standardized value. Scriven (1967) and Glas (1969) said that evaluation is an effort to explore the benefit and use of the program, activity, and so on. Malcom and Provos in Farida (2000) viewed evaluation as the difference between the fact and the standard to measure its dispute. Baumgartner and Jackson in Imam (2004) saw evaluation as an activity that provides meaning to the goal achievement. This activity must be well conducted to guarantee the appropriate decision. Philips and Homack in Imam (2004) said that evaluation is a complicated term which consists of decision making or consideration about the students achievement laid on qualitative and quantitative data.

According to the above theories, evaluation in this context is concluded as the process to make a policy, decision based on the 
relevant data. The process includes data collection, data consideration which based on certain standard.

Many definitions about program evaluation are given. Paulson in Grotelueschen $(1976 ; 17)$ stated that program evaluation is testing process towards an object or an event by using some specific measurements in purpose of establishing the appropriate decisions. Based on the definition, it is also in common border to explain program evaluation as a testing activity to the facts or reality as the source of decision. Another expert, Alkin $(1981 ; 11)$ defined this as the process related to preparing some decision areas through information selection, data collection and analysis, and report to help the decision makers in deciding some options.

Mugiadi (1980) explained program evaluation as an effort of collecting information about a program, activity, or project. The information is useful in decision making, mainly to improving the program, designing a more comprehensive forthcoming program, dismissing an activity, or spreading the ideas that underlie a program and activity. The information must be empirical, practical, effective and relevant to the standard values.

Syamsu Mappa (1984) defined extracurricular program evaluation as the activity to determine the success or the failure of a educational program. Moreover, Stake (1975) illustrated program evaluation is an activity to response the ongoing, late or even the forthcoming program. He said that the academic program evaluation is straightly oriented on activities in the program implementation and it is done to response the concerned parties who need the information.

According to the above definitions, it is concluded that program evaluation is a systematical activity to collect, process, analyze, and perform the data as input in making decision. Data is the fact, explanation, or information that can be measured.

Tyler in Suharsimi (2007) stated that program evaluation is done to get a view of whether the educational goals have been achieved. Cronbach and Stuffleben in Suharsimi
(2007) said that the orientation of program evaluation is to provide information for decision makers. Stufflebeam and Mulyasa (2003) defined evaluation is the process that used to measure the achievement of the program.

Ornstein (1989) stated evaluation as sustainable process which began with planning phase and following up the result. It is important to know the real progress of a program. Suharsimi (2007) said that program evaluation is aimed to get a view on the extent of program implementation that provide decision whether a program would be dismissed, revised, continued or even spreaded. This definition implies that the evaluation leads us to decide a program to (1) continue, (2) revise, (3) dismiss, or (4) reorient in order to make new objectives, goals and alternatives.

CIPP model evaluation is one of evaluation models that very systematic and extensive used by the experts. Model CIPP was developed by Daniel L.Stuflebeam and colleagues (1967) in Ohio State University. CIPP stands for Context evaluation, input evaluation, process evaluation, and product evaluation.

\section{Context evaluation}

Context evaluation is the beginning evaluation that related to program area review, including the study of students needs and all the problems concerned with supportive or obstructive factors. This phase produces two decisions; changing / revising the program or continuing the program which implies that evaluation input will be the next step to take.

\section{Borg and Gall (1979) provided} that "context evaluation involves analysis of problems and need in a specific educational setting. A need is defined as discrepancy between an existing condition and desire condition". Context evaluation involves the analysis of the basic of the program itself, the needs of the program as well as the things related to the program. It also illustrates the purpose of the program that unachievable. Omstein (1989) stated that context evaluation is a study of the area in which the program takes 
place. Stuflebeam and Ornstein (1989) said that it is a basic type of evaluation. This is significantly applicable to determine the rational objectives. This explains the relevant areas between the existing condition and the expecting one.

Context evaluation leads to the needs and opportunities. It is the analysis of a situation; reading the reality in which people finds themselves, while judging that condition is relevant to their needs.

\section{Input Evaluation}

Borg and Gall (1979) described input evaluation as an evaluation of sources and strategies used to gain the purpose of the program. Omstein (1989) said that it was designed to provide information in deciding the way to utilize all the sources. This evaluation is specific and microanalysis. Input is formed by context evaluation.

Borg and Gall (1979) explained that information derived from this evaluation would be useful in measuring the effectiveness of strategy used in program. It must be applicable in deciding the ethical and legal aspects of the strategies.

\section{Process evaluation}

Borg and Gall (1979) explained that process evaluation involves data collection of the ongoing program. It concerns with the extent of the program based on the designed purpose. Ornstein (1979) said that process evaluation is used to determine the accuracy between plan and actual activities.

Stufflebeam and Ornstein provides three main strategies in process evaluation; 1) detecting or predicting the damage or deficiency in procedure design, or the implementation in its diffusion phase, 2) providing information to programmed decision and 3) maintaining procedure records. First strategy is crucial to modify and monitor the potential sources. The logistic operation is also wholly evaluated. The second one involves projection and attendance of the decision before it is programmed. The last strategy heads for the main part of project design, for example, the content choice in specific, learning strategy planning and others.

\section{Product Evaluation}

It judges the program based on its purpose. This evaluation provides evaluator of information in establishing the decision of continuing, stopping or modifying the program. Ornstein (1979) explained that evaluator collecting data in purpose of measuring the product.

Ornstein (1979) described that product evaluation serves information about the product that helpful in making some decisions about the program. Stufflebeam and Omstein (1989) provided 4 steps of decision making; (a) planning the decision after the context evaluation,(b) structuring decision after input evaluation, (c) implementing decision which followed by the process, (d) investigating the decision after the product evaluation.

Ornstein (1979) explained that CIPP Model provides comprehensive review of total program evaluation that consists of designing, developing, implementing and evaluating. It is more about the emperical study of the program.

Final purpose of program evaluation is giving the appraisal of the program and recommendation for the concerned parties.

Moreover, Nadler (1982) added that program evaluation is a systematical process which some steps follow: a), guarantee the party that support the program as well as give the appraisal towards its result, as public institution / government, senior management and community, b). identify the people involved in planning and supervising the evaluation, c) precisely define the purpose and how the result will be used, d) make a specific measurement and the evaluation formula, e) decide the party who will supply all the needs, f) specifically determine the strategy of collecting data, g)decide the procedures, h) determine the criteria of the decision, i) establish the time and budget needed to conduct the evaluation, j) complete evaluation, recommended formula and prepare the report, $\mathrm{k}$ ) response the recommendation towards learning activities and education unit. 
Participatory Action Research (PAR) System

Definition of PAR must be explained by the meaning of Participatory, which always related to the word of Participation. Both participatory and participation is two words that always correlated to development.

Pidarta(1988)described participatory der ived from the word participation, that is the involvement of a person or some people in an activity. Meanwhile, FAO in Mikkelsen (2001) said that participatory (participation) has some meanings as; a) voluntary contribution of society in a project without the right of making decision, b) "to sensitive"/ to make society to be more sensitive in improving their capability of accepting and responding the development program, c) an active process which means that concerned people or groups are able to take initiative and using their right to do something, d) dialog strengthening between local community and the staff conducting the plan, implementation, and monitoring to gain information about local context and social impacts, e) voluntary involvement of society in the effort to change their condition, f) social involvement in self, life and physical development.

Participatory development is new field that in process on internalization and this evolves many definitions of participatory itself. Fernandes (1993) described that the actor /participant is not merely an object of others study, this participant is active in influencing the process and knowledge transfer. He also stated that participatory is an effort to test the tendency of knowledge professionalization and centralization. This tries to make sure that all of the result and implementation would not be manipulated and reflect the social needs as well as to guarantee that every product of knowledge is belong to its local or legal community.

There are some definitions of PAR ( Participatory Action Research). Shobaruddin (2008) stated that PAR basically is a specific form of RRA (Rapid Rural Appraisal) that formerly developed. PAR is a technique of research that developed in $1980 \mathrm{~s}$ as an alternative and complement of classic study with special features, those are; participation strengthening and local community involvement. PAR is a method in which the researchers and society are able to systematically and quickly collect information of general analysis about a topic that need appraisal, feasibility studies, identification and evaluation of rural project.

Shobaruddin (2008) also explained that PAR is a development research activity in society to meet the local needs, instead of designed needs. This activity does not need a regular intervention schedule, period-based and specific budgeting, project structure or even one-way command delivered from project to its targeted groups. The problem is how the inhabitants / local community are willing to give their attention to the new and different things. The used method is motivation and animation, not selling or pushing.

Based on the explanation above, it is concluded that PAR (Participatory Action Research) is a development activity that involves local society who work together with the staff in a social - reflective program. PAR is a program that conducted in social research and social empowerment that has a certain purpose.

Moreover, Fernandes (1993) also added that PAR is aimed to extricate of direct control from professional researcher. The research must be consistent with its definition. The approach tries to reflect the needs of the marginal groups in society as well as become the part of social awareness.

These statements make some experts tend to see PAR as non- objective development approach. It is said that the approach is merely protecting the marginal and low class community.

Pidarta (1998) defined that the purpose of PAR is to involve all the parties that in a program to find the root of the problem as well to find the solution from the designed program. In other words, Mikkelsen (2001) argued that PAR is aimed to overcome the problem in a program, from society and organization, which produces the result that indirectly and incompletely remove the problem itself. 
The purpose of PAR in society is to help them to be more independent and capable of identifying, solving problem, and executing an activity by themselves or collaborate with another non-local organization.

A program needs process and phase to pass out. Fernandes (1993) said that even the program is basically based on the social needs, but the implementation ideally involves the powerful parties from both inside or outside the community. The fact is that the participatory must be revolving and well-organizing. It means that all parties can go by the process without the outsiders attendance. This implies that the outsiders are just the supplement.

Mikkelsen (2001) stated that the techniques in PAR are complement to the former methods. PAR is not designed to excessively provide the assignment or analysis for its researchers. The common techniques used in PAR are dialog, collecting information, analysis and mobilization.

\section{Social internship Program Using Particippatory Action Research System}

Social internship Program (to be called Kukerta) is a form of mandatory education program for the Graduate students (S1). It is held by serving the learning experience on field and outside class, directly identifying, formulating and overcoming the development problems had by the society.

Sudrajat (2008) stated that Kukerta is a form of University Tri Dharma. It ideally covers three main purposes. First, as the learning mode for students to apply the theories that have been discussed in class, according to their own field. Second, Kukerta provides an extra values to improve the social life condition. Third, it is a media to build the collaboration between the university and society, as well as the promotion for the university itself.

In Manual Guidelines Book of Social Internship Program of IAIN Sultan Thaha Saifuddin Jambi (2011), it is explained that Kukerta is a compulsory - intracurricula activity that integrates three university philosophy; education, research and social work.

Next, based on the definition of Kukerta and PAR, it is assumed that Kukerta using PAR System is the part of intracurricula activity by using alternative method as a part of social empowerment, putting community as an object and learning sources, and involving some phases of identifying and analyzing the problem followed by real action or implementation to strengthen the social position in solving their own problems.

Social Internship Program related to rural development is aimed to; a) improve orientation, indifferent, and dedication of the students, as well as to improve the social participation in development, b) improve the harmony and relationship between the university and local government, c) supporting the rural development program, d) to increase the function and the involvement of the rural development organization.

The implementation of PAR system Kukerta leads the students to use the data collection technique of PRA (Participatory Rural Appraisal ). It is defined by measurement, investigation, and observation on the social condition. This also uses the technique and tools to facilitate the rural society in order to empower them in analyzing their own life condition and capable of making and implementing the plan.

There are some methods in PAR System Kukerta; mapping, transector, field note, venn diagram, timeline, trend and change diagram, cycle diagram, matrix ranking, problem solving, and problem tree analysis.

Sudrajat (2008) said that Kukerta has to follow the following steps; relationship opening, relationshing maintaining, relationship building and relationship on conclusion.

\section{CONCLUSION}

According to the general and specific findings of the research, it is assumed that ; first, context evaluation of PAR system Kukerta programs is actually having many deficiencies and weakness in both determining the needs as 
well as the purpose of Kukerta program. Therefore, it needs some improvements or revision. Second, input evaluation of PAR system Kukerta shows some weakness from the students and the internship supervisors / advisors. Both students and internship supervisors have to be firstly provided by training on PAR system Kukerta. Third, process evaluation on the program is also lack of the relevant activities towards students' needs and program realization. Fourth, product evaluation reveals that there is no significant result of the program, physically or non-physically. The program can be continued with some improvements and revision on its implementation.

\section{RECOMMENDATION}

Based on the research findings, it is highly recommended to the concerned parties: 1. Head of University of IAIN Sultan Thaha Saifudin Jambi; to improve the implementation of PAR system Kukerta Program so the students can give their real contribution and participation. 2. Kukerta Executing Board; to increase the PAR system from the beginning until its end. This could be fulfilled by training, discussion, and other activities related to Kukerta. 3. Lecturers / internship supervisors; to give or deliver the guidance, motivation and support to the students appropriately, wholeheartedly, and factually in order that they serve the best to the social development in each location they are placed on. 4. Society / community of the Kukerta takes place; to give the attention, support, critics and also guidance to the students that the implementation of the program would be more meaningful and trustful for the sake of the social development. 5. The forthcoming researchers; to conduct the comprehensive research on evaluation of PAR system Kukerta Program as seen from other sides.

\section{REFERENCES}

Anderson, S.B. \& Ball, S. (1978). The Profession and Practice of Program
Evaluastion. Sans Francisco: Jossey-Bass Publishers.

Arikunto, S., Jabar, A., \& Safruddin, E. (2004). Evaluasi Program Pendidikan. Jakarta: Bumi Aksara.

Arikunto, S. (1986). Dasar-dasar Evaluasi Pendidikan. Jakarta: PT. Bina Aksara

Borg, W.R. \& Damien, G.M. (1979). Educational Reseach an Introduction. New York Longman.

Brannen, J. (2002). Memadu Metode Penelitian Kualitatif dan Kuantitatif. Yogyakarta: Pustaka Belajar.

Faisal, S. (1990). Penelitian Kualitatif: Dasardasar Aplikasi. Malang: YA3.

Farida, Y.T. (2000). Evaluasi Program. Jakarta: Rineka Cipta

Farmer, J.A. \& Papagianis, G. (1975). Program Evaluation: Functional Education for Family Life Planning, III. New York: World Education.

Fernandes, W. \& Tendon, R. (1993). Riset Partisipatoris Riset Pembebasan. Jakarta: Gramedia Pustaka Utama.

Grotelueschen, A.G. Program Evaluation. (dalam Alan B. Knox). (1980). Developing, Administering, and Evaluating Adult Education. Sans Francisco: Jossey-Bass Publishers.

Guba, E.G. Lincoln YS. (1981). Effective Evaluation. San Francisco. Jossey Bass.

Hamalik, O. 1989. Teknik Pengukuran dan Evaluasi Pendidikan. Bandung: Mandar Maju.

http://akhmadsudrajat. Wordpress.com/2008/02/14/ PendekatanSosial-dalam-kegiatan $\mathrm{kkn} /$. Retrieved on March 10, 2008.

http://LpmSigma.cq.cc/index.php?option $=$ com content\&task $=$ view\&id=18xitemid $=1$. Retrieved on April 6, 2008.

http://publik.brawijaya.ac.id/?hlm=jedliq\&ed $=1$ $157043600 \&$ edid $=1145933808$. Retrieved on April 19, 2008. 
http://www.denpost.net/2008/08/19/negara.htm. Retrieved on April 26, 2008.

http://www.Sunanampel.ac.id/berita/detail.php?id=67. Retrieved on April 26, 2008.

http:/www.Fitrotunniswah/search?q= eache: 6087m VSjFcEj:fia-S1 unipdu.blogspot.com. Retrieved on March 10, 2008.

IAIN STS Jambi. (2011). Buku Pedoman Kuliah Kerja Nyata IAIN STS Jambi ke-37 Gelombang I Tahun 2011. Jambi: Lembaga Pengabdian kepada Masyarakat IAIN STS Jambi.

J.P. Dickenson. CG. Et al. (1992). Geografi Negara Berkembang. London dan New York. Methenn.

Lincohn, Y. S, Guba, E. G. (1984). Naturalistic Inquiry. London: Sage Publication.

Made, P. (1988). Perencanaan Pendidikan Partisipatori dengan Pendekatan Sistem. Jakarta: Depdikbud Dirjen Perguruan Tinggi Proyek Pengembangan Lembaga Pendidikan Tenaga Kependidikan.

Mikkelsen, B. (2001). Metode Penelitian Partisipatoris dan Upaya-upaya Pemberdayaan: Sebuah Buku Pegangan bagi Para Praktisi Lapangan. Jakarta: Obor Indonesia.

Muri, Y. (2005). Dasar-dasar dan Teknik Evaluasi Pendidikan. Padang: Universitas Negeri Padang.

Ornstein, A.C., Hupkins, F.P. (1989). Curriculum Foundation Principles and Issues. New Jersey: Prentice Hall, Englewood Cliffs.

Popham, W.J. (1975). Educational Evaluation. New Jersey: Prentice-Hall, Inc.

Sodikun, I. (2005). Kumpulan Makalah Penilaian dan Evaluasi Pendidikan dalam Berbagai Seminar dan Pelatihan. Padang: Universitas Negeri Padang.

Sudjana, D. (2006). Evaluasi Program Pendidikan Luar Sekolah. Bandung: PT Remaja Rosdakarya
Sugiyono. (2010). Metode Penelitian Pendidikan Pendekatan Kuantitatif, Kualitatif. Bandung: Alfabetta.

Syaodih, N. (2005). Metode Penelitian Pendidikan. Bandung. Rosda Karya.

Tyler,W. (1969). Education Evaluation. Chicago. New Roles New Means. Illionois: The University Press.

Worthen. B.R. \& Sanders, J.R. (1987). Educational Evaluation Alternative Approaches and Practical Guidelines, New York. Pitman Publishing Inc. 